ROLAND PREJS OFMCap* - LUBLIN

\title{
ARCHIWUM KOŚCIELNE. ROLA I ZNACZENIE JAKO MIEJSCA PRZECHOWYWANIA DOKUMENTÓW PRZESZŁOŚCI
}

\section{Podstawowe pojęcia}

Omawiając zagadnienie zawarte w tytule, musimy najpierw wyjaśnić i uściślić pewne terminy i pojęcia $\mathrm{z}$ zakresu archiwistyki. Wiele $\mathrm{z}$ nich używamy bowiem w znaczeniu potocznym, podczas gdy w archiwistyce mają one sens ściśle określony ${ }^{1}$. I tak nazwą ,archiwum” zwykliśmy określać wszelkie składnice dokumentów, zarówno dawnych jak i służących do bieżącego urzędowania. Tymczasem „archiwum” w sensie ścisłym, to miejsce przechowywania dokumentów wycofanych już z bieżącego urzędowania, mających jednak znaczenie dla poznania przeszłości. Miejsce przechowywania dokumentów służących do bieżącego urzędowania poprawnie winno nazywać się „registraturą”, ewentualnie „archiwum zakładowym”2. „Zespół akt”, to akta pochodzące z jednej kancelarii, a konsekwentnie z jednej instytucji: pisma przychodzące do tejże kancelarii oraz kopie, względnie regesty pism wychodzących z niej. Nie jest ,zespołem akt” grupa akt wytworzonych przez jednostkę organizacyjną tejże instytucji (wydział, referat),

* O. Roland Prejs OFMCap - dr hab historii, profesor w Instytucie Historii Kościoła, Wydział Teologii KUL.

${ }^{1}$ Przykładowo wymieniamy w tym miejscu podręczniki archiwistyki, zawierające podstawowe pojęcia i ich wyjaśnienie: H. Robótka, B. Ryszewski, A. Tomczak, Archiwistyka, Warszawa 1989; Metodyka pracy archiwalnej, red. S. Nawrocki i S. Sierpowski, Poznań 1992; H. Robótka, Wprowadzenie do archiwistyki, wyd. 2, Torun 2003. Zagadnienia te, opracowane bardziej lub mniej obszernie, można znaleźć w każdym podręczniku archiwistyki.

${ }^{2}$ Ściśle rzecz biorąc, istnieje różnica pomiędzy archiwum zakładowym a registraturą. Registratura bowiem, to miejsce przechowywania akt służących do bieżącego urzędowania, archiwum zakładowe natomiast, to miejsce przechowywania akt, które zostały już wycofane (względnie są $\mathrm{w}$ trakcie wycofywania) z bieżącego urzędowania, nie zostały jednak jeszcze odprowadzone do archiwum, przechodzą lub przejdą w niedługim czasie brakowanie oraz porządkowanie i dopiero wtedy staną się dostępne do badań naukowych. Por. H. Robótka, Wprowadzenie do archiwistyki, wyd. 2, Toruń 2003, passim. 
chyba, żeby z jakichś powodów taka jednostka organizacyjna prowadziła własną, odrębną kancelarię i pismom, zarówno wychodzącym jak i przychodzącym nadawała własne numery dziennika podawczo-odbiorczego. W tym ostatnim wypadku trochę komplikacji może nasuwać sposób funkcjonowania niektórych urzędów w XV-XVIII w., w których trudno rozgraniczyć działania kancelarii głównej i poszczególnych jednostek organizacyjnych, ale zaliczmy to do przypadków szczególnych, które domagałyby się osobnego omówienia na innym miejscu.

Przypomnijmy też tutaj nazwy i cechy podstawowych form kancelaryjnych. Są to dokumenty samoistne (dyplomy), księgi wpisów i akta sprawy. Dokument samoistnyjest pojedynczym dokumentem, wydawanym w konkretnej sprawiei wręczanym odbiorcy, stąd należy do jego kancelarii, nie zaś do kancelarii wystawcy. Kancelaria wystawcy albo nie zachowywała dla siebie żadnej kopii wydanego dokumentu, albo sporządzała jego regest w księdze regestów. W odniesieniu do ziem polskich ta forma kancelaryjna pojawiła się z chwilą przyjęcia chrześcijaństwa, choć zaistniała na szerszą skalę dopiero w wiekach następnych i przetrwała zasadniczo do końca XV w., aczkolwiek pojedyncze dokumenty samoistne pojawiały się jeszcze w XVIII w. W okresie powszechnego funkcjonowania dokumentu samoistnego materiałem powszechnie służącym do sporządzania dokumentów pisanych był pergamin, stąd dokumenty samoistne są często dokumentami pergaminowymi, ale nie jest to zasadą: znamy papierowe dokumenty samoistne i to w całkiem obfitej ilości. Dokumenty samoistne łatwo mogły ulec zniszczeniu w pożarach czy grabieżach, a ze względu na istnienie w jednym egzemplarzu i brak kopii ich treść zostawała zapomniana. Celem jej utrwalenia dokumenty takie albo kopiowano, nieraz po wielu latach, albo ich treść wpisywano do innych dokumentów, czyli sporządzano tzw. transumpty i inserty.

Księga wpisów pojawiła się na ziemiach polskich również po przyjęciu chrześcijaństwa, na dobre rozwinęła się w XIV/XV w. i stosowana była do końca Rzeczpospolitej przedrozbiorowej. Początkowo były to nekrologi, kroniki, roczniki i kalendarze (pomijamy w tym miejscu księgi liturgiczne, tym bardziej rękopisy dzieł, jako należące do rękopisów bibliotecznych, a nie do archiwaliów), jednakże od XIV/XV w. mamy do czynienia z księgami wpisów w ich najbardziej klasycznej postaci, jako liber actorum, czyli księgą, w której zapisywano wszelkie czynności danego urzędu w porządku najczęściej chronologicznym, bez względu na problemy, których czynności te dotyczyły. W księdze wpisów spotykamy też odpisy dokumentów samoistnych, tych zwłaszcza, których treść z jakichś powodów była szczególnie ważna dla posiadacza. Mówimy wówczas o tzw. oblatowaniu dokumentów do ksiąg wpisów, zwłaszcza do ksiąg ziemskich i grodzkich, w zależności od urzędu, który dokonywał oblatowania. Szczególną postacią ksiąg wpisów są tzw. kopiariusze - księgi zakładane specjalnie w tym celu, aby wpisywać do nich dokumenty samoistne, celem zachowania ich treści w razie, gdyby sam dokument uległ zniszczeniu. Inną szczególną formą ksiąg wpisów są księgi wizytacyjne, ale o nich będzie mowa w osobnych artykułach zawartych w niniejszym tomie.

Korzystanie z księgi wpisów nastręczało już niemało trudności w okresie jej prowadzenia, dlatego w XIX w. księga wpisów została wyparta przez następną 
formę kancelaryjną, czyli akta sprawy, choć w pewnej, ograniczonej postaci pozostała nadal w wielu kancelariach, zwłaszcza kościelnych, ale coraz częściej stawała się księgą tematyczną, w której odnotowywano ściśle określony zakres spraw, np. udzielanie święceń. Akta sprawy przyszły na ziemie polskie wraz z kancelariami zaborców, którzy instalując swoją administrację, przynosili też funkcjonujące u siebie systemy i formy kancelaryjne. Ta dość wygodna w praktyce urzędowej forma kancelaryjna trwa do naszych czasów. W aktach sprawy spotykamy się z odpisami dokumentów samoistnych względnie z wypisami z ksiąg wpisów, ale nie są to częste sytuacje. Wspomnieliśmy, że akta sprawy przyszły na ziemie polskie wraz z kancelariami zaborców. Zabory wprowadziły na ziemiach polskich ogromne przekształcenia $\mathrm{w}$ zakresie istnienia i funkcjonowania instytucji kościelnych, zmieniły stosunki własnościowe (np. wywłaszczenie majątków kościelnych), dlatego dawne dokumenty erekcyjne instytucji kościelnych czy nadające majątki w wielu wypadkach straciły na znaczeniu³. Czy zastosowanie technik elektronicznych do przechowywania wytworów działalności kancelarii wpłynie na powstanie nowych form kancelaryjnych, w tym miejscu nie przesądzamy i jest to sprawa przyszłości, którą archiwistyka się nie zajmuje.

\section{Z dziejów dokumentów kościelnych}

Kościół zawsze doceniał tworzenie i gromadzenie dokumentów pisanych świadczących o jego przeszłości, choć oczywiście w różnych epokach powstawała różna ilość tychże dokumentów i pozostawała ona w zależności od stopnia upowszechnienia się praktyki utrwalania na piśmie wszelkich przejawów działalności społecznej. Nawet w pierwszych wiekach chrześcijaństwa, kiedy Kościół nie miał statusu instytucji działającej publicznie, powstawały pisane dokumenty, ale przeważały wśród nich traktaty teologiczne, martyrologia $\mathrm{z}$ aktami męczeństwa oraz postanowienia soborów i synodów; inne dokumenty powstawały w mniejszym stopniu. Od czasu „wyjścia z katakumb”4 narasta zasób dokumentów dokumentujących powstanie instytucji kościelnych, a więc diecezji, kapituł, klasztorów, szkół, szpitali itp. Wskutek przyjmowania rozmaitych darowizn coraz częściej sporządzano w Kościele dokumenty pisane mające poświadczyć fakt donacji. Rozwój szkolnictwa kościelnego pociągał za sobą sporządzanie wykazów uczniów, a następnie także odnotowywania ich postępów w nauce. Dokumentami, do których przywiązywano wielką wagę, były katalogi biskupów wraz z wykazaniem sukcesji apostolskiej.

${ }^{3}$ H. E. Wyczawski, Przygotowanie do studiów w archiwach kościelnych, Kalwaria Zebrzydowska 1990, s. 29-45; S. Nawrocki, Rozwój form kancelaryjnych na ziemiach polskich od średniowiecza do końca XX wieku, Poznań 1998, s. 93-95.

${ }^{4}$ Pojęcie „wyjście z katakumb” traktujemy umownie, nie wchodząc w to, na ile rzeczywiście życie Kościoła w pierwszych trzech wiekach odbywało się w katakumbach. Chodzi nam o sytuację, w której Kościół nie miał statusu instytucji publicznej, a wyznawanie wiary chrześcijańskiej często (choć nie zawsze) pociągało za sobą męczeństwo. 
Prawdziwa „eksplozja” dokumentów pisanych w Kościele pojawiła się w średniowieczu. Złożyło się na to wiele przyczyn, między innymi upowszechniająca się praktyka dokumentowania na piśmie wszelkich istotniejszych wydarzeń życia społecznego, mnożenie się instytucji kościelnych, w szczególności wykształcenie się rozmaitych urzędów i instytucji wspomagających biskupa w zarządzie diecezją, jak archidiakon, oficjał czy kapituła katedralna, narastanie majątków kościelnych, rozwój szkolnictwa, wieloraka działalność biskupów, zarówno ściśle kościelna jak też polityczna, gospodarcza i kulturalna. Wpływ na liczebny rozwój kościelnych dokumentów pisanych wywarły też zakony, dbające o udokumentowanie zarówno faktu założenia klasztoru, jak też otrzymanych lub nabytych posiadłości, spisu zmarłych zakonników i dobroczyńców, wykazu zobowiązań, np. co do odprawiania mszy świętych za zmarłych dobroczyńców. Do szczególnego znaczenia w praktyce zakonnej urosły metryki, czyli księgi przyjętych i składających śluby zakonne, a także kroniki, nekrologi (spisy zmarłych zakonników, nazywane też mortuologiami lub menologiami) oraz księgi majątkowes.

Wejście w życie trzeciej formy kancelaryjnej, czyli akt sprawy ubogaciło rodzaje dokumentów kościelnych, zwłaszcza, że upowszechnienie się umiejętności czytania i pisania wśród szerokich warstw ludności oraz ułatwienie technik sporządzania dokumentów pisanych sprzyjało dokumentowaniu na piśmie nie tylko wszelkich przejawów działalności, ale także procesu podejmowania decyzji. W II połowie XIX w. upowszechnia się maszyna do pisania, która przez cały XX w. przechodzi modernizacje ułatwiające posługiwanie się nią oraz staje się narzędziem codziennego użytku w urzędach. $Z$ kolei poszczególni urzędnicy (referenci, sekretarze) na każdym etapie przygotowywania decyzji zwykli na piśmie sporządzać opinie w załatwianej sprawie i propozycje dekretów. Wszystko to z jednej strony umożliwiało dokładniejsze prześledzenie faz działalności, z drugiej jednak spowodowało narastającą lawinę dokumentów pisanych, o bardzo różnej przydatności do urzędowania, niemniej zachowywanych w kancelariach, a potem w registraturach, skąd trafiały do archiwów. Wśród dokumentów kościelnych w tym okresie mamy więc nie tylko akty normatywne (ustawy, dekrety) i konstytutywne (dekrety powołujące lub znoszące jakąś instytucję), ale też rozporządzenia i protokoły wizytacyjne, prośby o decyzje i same decyzje wydane w konkretnych, nieraz bardzo szczegółowych sprawach, dokumenty święceń i nominacji na stanowiska kościelne, korespondencję z władzami państwowymi i pomiędzy różnymi instytucjami kościelnymi, projekty planów duszpasterskich i raporty z ich wykonania, akta majątkowe, w tym kasowe, budowlane, dowody własności, zbycia i nabycia, by wymienić tylko niektóre tytułem przykładu. Akta sprawy zazwyczaj były gromadzone w teczkach czy poszytach, obejmujących dokumenty dotyczące bądź jednej sprawy, bądź grupy spraw o podobnym charakterze, dzięki czemu odnalezienie określonych dokumentów było ułatwione, jeśli tylko znało się obowiązujący system kancelaryjny lub dysponowało się tzw. wykazem akt ${ }^{6}$. Niemniej zdarzało się, choć rzadko, że akta grupowane były w teczkach nie rzeczowo (te-

${ }^{5}$ Wyczawski, Przygotowanie, s. 225-291, 301-313.

${ }^{6} \mathrm{R}$. Kufel, Kancelaria, registratura i archiwum parafialne na ziemiach polskich od XII do początku XXI wieku, Zielona Góra 2005, s. 49-58. Zawarte tam uwagi odnoszą się przede wszystkim 
matycznie), lecz chronologicznie. Tak było np. w II połowie XIX w. w Konsystorzu Diecezji Lubelskiej, gdzie poszczególne teczki obejmują wszystkie sprawy zdanego roku? . Był to oczywiście pewien konserwatyzm w praktyce kancelaryjnej, niemniej zdarzał się tu i ówdzie.

Szczególną rolę pełniły dokumenty, o których trudno powiedzieć, że zostały wycofane z urzędowania. Były to świadectwa o życiu świętych i błogosławionych oraz kandydatów na ołtarze, czy dokumenty poświadczające ich kult. Podobny charakter miały relacje o uzyskanych łaskach w sanktuariach, zwłaszcza maryjnych. Swoista przydatność tych dokumentów do urzędowania nie kończyła się właściwie nigdy, a przynajmniej istniała tak długo, jak długo istniał dany ośrodek kultu religijnego. Do tej grupy dokumentów zaliczyć też trzeba akty erekcji kościołów czy klasztorów, akty erekcji kapituł, prepozytur, altarii czy mansjonarii, przywileje odpustowe, poświadczenia autentyczności relikwii. Dokumenty te zachowywały bieżące znaczenie dopóty, dopóki istniała dana instytucja kościelna, odpust funkcjonował w życiu religijnym miejscowej społeczności wiernych, a relikwie znajdowały się w świątyni. Racje te przesądzały o tym, że dokumenty tego rodzaju otaczano szczególną pieczołowitością, a częstokroć nie umieszczano ich $\mathrm{w}$ archiwum, lecz w świątyni, oprawione $\mathrm{w}$ ramy i zawieszone przy odnośnym ołtarzu lub w zakrystii. Nie znaczy to, że zawsze omijały je klęski: wraz ze świątynią padały pastwą pożaru, nieco rzadziej rabunku, niekiedy po prostu ulegały zniszczeniu, albo przy kolejnej przebudowie kościoła trafiały do schowka, w którym z biegiem czasu zostawały zapomniane ${ }^{8}$.

\section{Z dziejów archiwów kościelnych}

Ojciec Hieronim Eugeniusz Wyczawski jest zdania, które w tym miejscu podzielamy, że w pierwszym okresie chrześcijaństwa w Polsce kancelarie biskupie nie istniały, w konsekwencji też nie istniały archiwa, nawet w znaczeniu składnic dokumentów. Według tegoż historyka atak kancelarie biskupie jak i związane z nimi archiwa są tworem późniejszym, powstałym dopiero w związku z narastaniem i zagospodarowywaniem majątków kościelnych. Natomiast rolę instytucji wytwarzającej i gromadzącej diecezjalne archiwalia kościelne, tak biskupie jak i własne, spełniały kapituły katedralne. Drugim miejscem, gdzie należałoby szukać najstarszych polskich archiwów kościelnych, są - według o. H. E. Wyczawskiego - najstarsze klasztory, zwłaszcza benedyktynów, cystersów i kanoników regularnych ${ }^{9}$.

do kancelarii parafialnej, można je jednak odnieść - mutatis mutandis - do każdej kancelarii kościelnej.

${ }^{7}$ Piszący te słowa stwierdził to z autopsji, podczas kwerendy przeprowadzonej w 1. 1998-2002, przy pisaniu rozprawy Zakonnicy franciszkańscy Królestwa Polskiego po kasacie 1864 roku. Dzieje - postawy (druk. Warszawa 2003).

${ }^{8} \mathrm{Na}$ ten temat por. uwagi zawarte w pracy R. Kufela, Kancelaria, passim, zwłaszcza s. 27-81.

${ }^{9}$ H. E. Wyczawski, Polskie archiwa kościelne, w: Księga tysiąclecia katolicyzmu w Polsce, cz. 
Na ziemiach polskich przynajmniej do końca XVIII w. nie istniały archiwa kościelne w znaczeniu współczesnym, a więc jako placówki naukowe, służące do badania przeszłości. Mimo, że dokument przestał być użyteczny w codziennej pracy kancelarii, częstokroć przechowywano go nadal w tejże kancelarii, wychodząc z założenia, że albo może się jeszcze przydać, albo powinien pozostać w miejscu wytworzenia. O roli kapituły katedralnej jako strażnika dokumentów kościelnych w ,archiwum kapitulnym”, wspomnieliśmy wyżej. To zadanie kapituły sprawiło, że świadomość znaczenia dawnych dokumentów dla badania przeszłości najszybciej pojawiła się w środowisku kapituł, zwłaszcza, że w szeregach kanoników nie brakowało ludzi uczonych i nawykłych do posługiwania się piórem, by wymienić Jana Długosza, czy już u schyłku Rzeczypospolitej Adama Naruszewicza ${ }^{10}$.

Rządy zaborcze, zabierając majątki kościelne, żądały też oddania dokumentów dotyczących tychże majątków. Wojny napoleońskie spowodowały zniszczenie i rozproszenie zbiorów kancelarii kościelnych, a przechowywane w nich dokumenty trafiały - bywało - w ręce prywatnych kolekcjonerów lub do rąk rozmaitych handlarzy ${ }^{11}$. Ten splot czynników: upadek Rzeczypospolitej przedrozbiorowej, kościelna polityka zaborców, zmiany majątkowe - wpłynęły na potraktowanie zachowanych dokumentów jako pomników dawnej świetności, utraconej wskutek okoliczności dziejowych, będącej jednak ideałem, do którego przywrócenia, choćby częściowego, należało zmierzać. Dołączył się do tego upadek bądź kasata wielu instytucji kościelnych (klasztorów, kolegiat, beneficjów prostych), a w konsekwencji nieprzydatność wielu dokumentów do bieżącego urzędowania ${ }^{12}$. Dlatego dopiero w okresie porozbiorowym pojawiły się na ziemiach polskich archiwa kościelne w rozumieniu instytucji gromadzących i udostępniających dokumenty przeszłości. W XIX w. pojawiły się również na ziemiach polskich pierwsze edycje źródeł - kodeksy dyplomatyczne. Ponieważ publikowano w nich dokumenty samoistne, pochodzące przede wszystkim z czasów średniowiecza, kiedy nie było jednoznacznego rozróżnienia pomiędzy dokumentami kościelnymi a świeckimi, dlatego w kodeksach znajdujemy wiele dokumentów dotyczących najstarszych instytucji kościelnych (biskupstw, kapituł, klasztorów).

Powstanie archiwów kościelnych na ziemiach polskich w całej pełni miało miejsce w okresie międzywojennym, na co wpłynęły m.in. postanowienia Kodeksu Prawa Kanonicznego ${ }^{13}$. Większość diecezji powołała wówczas do życia archiwa diecezjalne ${ }^{14}$. Inaczej wyglądała sprawa $\mathrm{z}$ zakonami ${ }^{15}$. Nieliczne zdobyły się na utworzenie własnych archiwów, co wynikało przede wszystkim z sytuacji za-

2, Lublin 1969, s. 57-59. Por. też na ten temat stwierdzenia W. Kujawskiego, Diecezja kujawskokaliska. Opracowanie historyczno-źródłoznawcze, Włocławek 2011, s. 266-267.

${ }^{10}$ Kujawski, Diecezja kujawsko-kaliska, s. 266-267.

${ }^{11}$ Wyczawski, Przygotowanie, s. 323-324; zob. także Tegoż, Polskie archiwa kościelne, w: Księga tysiąclecia katolicyzmu w Polsce, cz. 2, Lublin 1969, s. 57-101.

${ }^{12}$ Kujawski, Diecezja kujawsko-kaliska, s. 267.

${ }^{13}$ Wyczawski, Polskie archiwa kościelne, s. 91-92.

${ }^{14}$ Wyczawski, Przygotowanie, s. 329-339.

${ }^{15}$ Pojęcia „zakony” używamy w tym miejscu w sensie szerokim, na oznaczenie wszystkich in- 
konów na ziemiach polskich. Niemal wszystkie stare zakony przeżyły bowiem w XIX w. kasaty klasztorów, a w ślad za tym rozproszenie własnych zbiorów archiwalnych. Po I wojnie światowej skupiły się przede wszystkim na odzyskiwaniu dawnych placówek i pomnażaniu stanu personalnego oraz podejmowaniu się właściwych sobie dzieł apostolatu ${ }^{16}$. Nowe zakony (powstałe w XIX w., lub nawet w I połowie XX w.) były instytucjami zbyt młodymi, by w ich wypadku można było mówić o tworzeniu archiwów w sensie naukowym: ich dokumentacja była przechowywana w bieżących kancelariach jako służąca do urzędowania. W czasie II wojny światowej zarówno archiwa jak i kancelarie poszczególnych urzędów kościelnych doznały tak wielkich strat $\mathrm{w}$ zasobach, że świadomość wagi dokumentów kościelnych dla badań nad przeszłością, połączona z odpowiedzialnością za ich zachowanie dla przyszłych pokolen, wzrosła znacząco. Następstwem tego było zorganizowanie na nowo archiwów zniszczonych lub zdekompletowanych oraz powołanie do istnienia archiwów w tych diecezjach lub zakonach, w których dotąd instytucje takie nie funkcjonowały ${ }^{17}$. Nie oznacza to bynajmniej, że na tym polu wszystko już zostało zrobione. Najpilniejsze chyba zadanie, to uporządkowanie i zinwentaryzowanie archiwów parafialnych, których stan pozostawia nierzadko wiele do życzenia, czemu zresztą trudno się dziwić: w pojedynczej parafii nie ma na miejscu nikogo, kto potrafiłby zająć się archiwaliami w sposób fachowy i miał nad nimi stały nadzór. Lepsza - wydaje się - sytuacja panuje w archiwach poszczególnych domów zakonnych, które na ogół, w zależności od przepisów obowiązujących w danym zakonie, po upływie określonego czasu przekazywane są do archiwum centralnego (generalnego lub prowincjalnego), aczkolwiek i tu nie wszystko funkcjonuje idealnie.

Kreśląc ogólne dzieje archiwów kościelnych na ziemiach polskich, nie można pominąć wkładu, jaki w kulturę archiwalną w Kościele polskim wniósł powołany w 1956 r. Ośrodek (od 2006 r. Instytut) Archiwów Bibliotek i Muzeów Kościelnych oraz jego faktyczny organizator i długoletni redaktor wydawanego przez tenże Ośrodek czasopisma „Archiwa Biblioteki i Muzea Kościelne”, ks. prof. dr hab. Stanisław Librowski ${ }^{18}$. Z nazwiskiem tym zetknął się każdy, kto w jakikolwiek sposób zajmował się archiwami kościelnymi w Polsce. Dokonania zarówno Ośrodka jak i Księdza Profesora, to zagadnienie na osobne omówienie.

$$
* * * * *
$$

Historyk, badając przeszłość, sięga przede wszystkim do archiwów, w których znajduje dokumenty powstałe w związku z zaistnieniem $\mathrm{w}$ przeszłości pewnych

stytutów życia konsekrowanego, bez względu na to czy w sensie kanonicznym są one zakonami, czy zgromadzeniami zakonnymi.

${ }^{16}$ Wyczawski, Przygotowanie, s. 327-329.

${ }^{17}$ Podstawowe informacje o archiwach kościelnych w Polsce wraz z krótką ich charakterystyką zob. Wyczawski, Polskie archiwa kościelne, s. 92-95; Tenże, Przygotowanie, s. 329-339; Archiwa Kościoła Katolickiego w Polsce. Informator, oprac. M. Dębowska, Kielce 2002.

${ }^{18} \mathrm{Na}$ temat tej instytucji i ks. prof. Librowskiego zob. M. Dębowska, Ośrodek Archiwów Bibliotek i Muzeów Kościelnych Katolickiego Uniwersytetu Lubelskiego Jana Pawła II 1956-2006, Lublin 2006. 
wydarzeń, godnych udokumentowania. Zasoby archiwów kościelnych są podstawowym świadectwem dziejów Kościoła, zwłaszcza wypełniania misji ewangelizacyjnej, sprawowania kultu, funkcjonowania instytucji kościelnych, realizacji miłosierdzia chrześcijańskiego, upowszechniania wiedzy i nauki, w tym kształcenia kadr duchowieństwa. Bez archiwów kościelnych trudno więc wyobrazić sobie znajomość dziejów Kościoła oraz roli, jaką odegrał w ciągu blisko dwóch tysięcy lat istnienia. Kościół w ciągu tego czasu wywarł ogromny, a dziś często zapominany lub świadomie przemilczany wpływ na kształtowanie się cywilizacji europejskiej, w dalszej zaś kolejności - cywilizacji światowej. Ten wpływ może być poznany i właściwie opisany tylko w oparciu o zachowane zasoby archiwalne.

\title{
THE ROLE AND IMPORTANCE OF A CHURCH ARCHIVE AS A PLACE TO STORE
} DOCUMENTS OF THE PAST.

\begin{abstract}
Summary
The article first presents the basic archival terminology, in particular "fond" and briefly explains characteristic features of chancery practices such as a self-contained document, a book of inscriptions, case files. The Church always paid a great attention to collecting and storing official documents created in connection with the implementation of evangelization and salvatory mission in the world. The collection of these documents grew bigger and larger as the literary culture became more common and the habit of documenting every activity in writing spread, which on a large scale occurred only in the Middle Ages. This is how the church archives were created, initially as repositories of documents. Archives in the modern sense, that is, academic institutions which collect documents relevant to understanding and study of the past appeared in the Polish land only at the end of the 18th century. Most of the Polish dioceses organized their archives in the interwar period and monasteries only after the Second World War. The Centre (Institute since 2006) for the Church Archives Libraries and Museums (established in 1956) together with the coorganizer of the Centre, the Rev. prof. dr hab. Stanisław Librowski, played an important role in the development of church archives in Poland.
\end{abstract}

